\title{
Transformative Learning Model for Character Building Pancasila Course to Support Peace, Justice, and Strong Institution in Indonesia
}

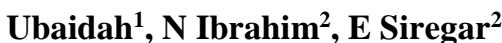 \\ ${ }^{1}$ Faculty of Humanities, Universitas Bina Nusantara, Jakarta, Indonesia \\ ${ }^{2}$ Faculty of Education Science, State University of Jakarta, Jakarta, Indonesia \\ 1ubaidah@binus.edu
}

\begin{abstract}
This research was aimed to develop transformative learning model for Character Building: Pancasila course and analyse the effectivity of transformative learning to support the achievement of intended learning outcomes in Pancasila course. The research was conducted by research and development methodology, while the learning model was developed based on transformative learning development framework for higher education. The learning model was tested feasible through several feasibility tests. The assessment result of learning shows that transformative learning model was effective to be applied in character building course to support peace, justice, and strong institution in Indonesia. The data shows that $90 \%$ of students were passed this course, and the effectivity test result shows that there was a significant difference between students learning result in experiment class compare with nonexperimental class.
\end{abstract}

Keywords: Pancasila, Course ,Transformative Learning

\section{INTRODUCTION}

"Transformative Learning" and "Character Building" are the two most challenging topics among research topics in higher education. Transformative learning was intended to be the most powerful learning approach to be applied in higher education based on consideration that transformative learning is a learning approach that focus on the metacognition process which is trigger student to transform the knowledge and skill into real condition to change the society [1]-[3]. This paradigm was suitable with the objectives of higher education to make a better quality of life through the application of the knowledge and science and best practice research [4], [5] Thus reasons become the common background of why transformative learning become the most trending research topics on developing new way of learning in higher education, despite the fact that transformative learning is the learning approach that intended for adulthood education [4], [6].

In the other side, social change was very affected by the character of individual that form a society, therefore, the good character of individual in a society will shape the structured society [7]. But we can't deny the fact that there is no single valid indicator to ensure the achievement of learning result in character education. Character, attitude, belief and other affective domain is abstract aspects, therefor the assessment for affective domain takes a long 
time so the educators and researchers face a challenge to make a conclusion of learning result in affective domain[8].

Every society have a different standard of good character, as in Indonesia, Pancasila become the ideology of state which is good character should be indicate through the implication of the five points of Pancasila, or we can call it "The Ideal Image of Indonesian People"[9]. Pancasila consist of five values that suitable to support peace, justice, and strong institution in Indonesia, it is; 1) Belief in the One and Only God, 2) a just and civilized humanity, 3) the unity of Indonesia, 4) democracy guided by the inner wisdom in the unanimity arising out of deliberations amongst representatives, 5) social justice for the whole of the people of Indonesia. Without clear understanding of Pancasila, it must be difficult to apply Pancasila as ideology of life [10] therefore to build good character nation, Pancasila become mandatory course for each education level in National Education Systems of Indonesia.

Based on those facts, we clearly see the urgency of building character of Indonesian nation, but as mention before, considering Pancasila as affective domain which is hard to ensure the effectivity become the main problem of Character Building: Pancasila course. As found in the preliminary research in Binus University, most students have lack of interest on the Character Building: Pancasila course, and the reasons mostly because it is lack of challenge and irrelevance with their career needs. To solve this problem, we propose the transformative learning approach as it have uniqueness component to make challenging yet relevant learning to make social change. Those we believe transformative learning will help the objectives of supporting peace, justice, and strong institution in Indonesia.

This research will discuss those two most challenging research topics; Transformative Learning and Character Building. As mentioned before, the application of transformative learning in higher education already take a place on research in education, but there are still lack of research that focus on developing transformative learning for character building. To be specific, the discussion on character building in higher education was also become main concern, specifically in Indonesia, according to the consideration that Indonesian government give high emphasize on character education[11]. The idea of introducing new way of learning in character building program really need attention, since the impact of character education in Indonesia still need to be reviewed and lack of evaluation report. That background triggers this research to develop transformative learning model in character building: Pancasila course in higher educationto increase the effectivity of character building program, especially in building Pancasila character which is have objective in building peace and justice character for the better Indonesia, to become strong institution.

\section{LITERATURE REVIEW}

This research was conduct in Binus University - Jakarta in 2016-2017. The aim of this research is to develop transformative learning model for Character Building: Pancasila course and analyse the effectivity of transformative learning to support the achievement of intended learning outcomes. The learning model was develop based on transformative learning development framework [12]

\subsection{Learning Needs Analysis}

The transformative learning model development started with learning need analysis step which is involving 40 respondents from 2 nd year students that just already take the Character 
Building: Pancasila course on previous period. As in this step, the researchers used questioner instrument that construct the ARCS instructional design theory by Keller which is consist of 4 criteria refer to 4 factors which is influenced the student motivation on learning, they are attention, relevance, satisfaction, and confidence [13].

Data from learning needs analysis showed that $80 \%$ of the respondents indicate the negative respond to the Character Building: Pancasila courses. In attention criteria that asking whether students interest to the course or not, $90 \%$ of the respondent doesn't interest to the course with various reasons which is $22 \%$ of it think that the course is boring, so they don't interest to the course. While in relevance criteria that focus on question whether students feel that this course meet their expectation and target, the respond remain negative which is $82 \%$ of respondent think that it doesn't meet their expectation with $28 \%$ of it think that the course is only repeat the content from senior high school and doesn't have any relevancy to their future expectation. The confidence criteria that focus on question whether students have any confidence that they will success on this course, $90 \%$ of the student think that they will success on this course with $33 \%$ of it think that the course is too easy, so they will easily success on this course. In the satisfaction criteria focus on the question whether the students feel the course have change their selves or not, the respond remain negative which is $75 \%$ of the student don't feel any changes on their selves after finishing this course.

The data in learning needs analysis showed that the main problem of current learning is lack of challenge and boring, so the students doesn't interest to the course. Beside of that, the students also don't find any relevancy of the learning with their expectation and real life, so they don't find this course is important to support their future career. Researchers then crosschecked the data to the lectures and we found that the current learning strategy and assessment are not suitable with students and intended learning outcomes.

\subsection{Instructional Program Design}

As learning problem already founded, the development process then continues to instructional program design which is constructed by the lecturer together with researchers as instructional designer (the instructional design team). The outcomes in this phase is an instructional program design and session plan which is consist of 15 sessions including mid exam and final exam. There are 7 main topics that delivered in this course, encompass: Pancasila as the Ideology of the State, Pancasila as Basic Fundamental of Science and Technology Development, The One and Only God, Justice and Civilized Humanity, The Unity of Indonesia, Democracy guided by the Inner Wisdom in the Unanimity Arising out of Deliberations amongst Representatives, Social Justice for all the Indonesian People, whereas the last 5 topics are the point of Pancasila.

The instructional program design then being reviewed by the expert in Pancasila and instructional design to ensure the design was meet the standard both on content context and on the instructional design context. The reviewers then assess the instructional program design with Likert scale assessment instrument which is instrument was validated by expert judgement. The researchers approach two Pancasila experts to review the content wise and collect some inputs. As for review the instructional design context, the researchers approach an expert in instructional design and collect some inputs. Based on the input, the researchers do some revision as follow up of the reviewer and ask the experts to assess the feasibility of instructional program design. 


\subsection{Implementation}

After all transformative learning component was ready, the transformative learning model was implemented in two class with 40 respondents. Lecturers was equipped with lecturer guideline to ensure the role as transformative learning facilitator are well applied.

\subsection{Evaluation}

To assess the effectivity of the learning model, researchers conduct comparison experiment by compare the final grade of experiment class with non-experiment class using T-test Analysis. Besides compare the final grade, researchers also distribute assessment questioner with Likert Scale to the experiment respondents with ARCS component, the same instrument that used in the learning need analysis step, to compare the result and ensure whether respondent have positive experience on learning with transformative learning model and whether transformative learning model solve the previous learning problem.

\section{RESULT AND DISCUSSION}

\subsection{Implementation of Transformative Learning Model}

The transformative learning model for Character Building: Pancasila course was designed for 15 session that supported the achievement of 7 learning outcomes which is broke down into 7 main topics. In each topic, there are 3 main transformative learning schemes; 1) learning in meaning schemes; 2) learning in new meaning schemes; and 3) learning in transformative means. In the learning in meaning schemes, students were introduced to the conceptual scaffolding delivered by lecturer as transformative learning facilitator. In learning in new meaning schemes, students were challenged with case or project, so they need to implement the knowledge they have before into real condition while lecturer still act as facilitator who trigger students on projecting the solutions. While in the learning in transformative means, students were having opportunity to share and present their experience on running the project in the class.

At a first time, researches face so many challenges on the implementation of transformative learning model at the first session. Both lecturer and students are not ready to change the learning paradigm as in the previous learning, lecturers are used to give only lecturing related to topics and students passively listen to the lecturers. That condition makes dialog session in the first meeting is challenging that the researchers need to involve on setting the active learning environment on the class. This condition makes learning in meaning schemes become so passive and the intended scaffolding doesn't achieve. As the scaffolding is not achieve, researchers expect the gap will be catch up in learning in new meaning schemes, but the reality, with insufficient scaffolding, the students become confuse and disorientation, so they need help on projecting their idea into feasible project.

Facing this challenge, the researchers change the approach by giving meta cognitive skills to the class, so we expect student will have basic skills in learning with transformative learning. Beside of that, researchers also brief lecturer to equip them on facilitating transformative learning. The learning pace become slower than the expected design, but we consider it as diffusion process since transformative learning is new for students and lecturer in Binus University. But through the time of implementation, student's skill on deliver their point of view and opinion were improve, while lecturer readier to become facilitator in 
transformative learning. After mid exam, students become more independent and have a full control of their own learning pace. Students become more active and creative on projecting the idea for their project.

One of the biggest project challenges for students is a humanity project relate to point two Pancasila where students are divided into 7 groups with 8 members in each group. In the learning in meaning schemes, students were refreshed with humanity value in Pancasila that focus on justice and civilized humanity. Since the Pancasila points already introduced to students since primary education, then the objective of this session is to link the humanity value in the real humanity project. Based on all knowledge that students got from scaffolding session, students start to generate their idea to make feasible humanity project and analyze all the necessary resources. In two weeks, student should run their project and prepare the project report, at this level, students are learning in new meaning schemes that push students to apply their knowledge to new setting.

The projects that initiate from students were so vary, from social campaign, charity event, and community development. On the next meeting, students should present their project and share their challenge and feeling through the project. At this level, the students were prepared to entry the learning in transformative means stage. Based on students' presentation, we can see how students should push their limit to run such a big project in a limit time, not to mention how they should handle the reality that not meet their expectation. When student should stand still on the humanity value while the real condition is a totally new for them, we can see how they start build their transformative means. The presentation and discussing session are to guide students in the designed track to achieve the learning outcomes, also to clarify students' confusion and disorientation as the foundation to learn in transformative means.

The session ended with self-reflective activity, facilitator ask students to tell their thought and feeling on the circle group discussion to sum up the whole session for humanity topic. This is important activity to ensure the achievement of learning goal, facilitator should put attention as a moderator of group discussion as well as assess the students' performance using checklist and rubrics.

Through the implementation process, we can conclude that transformative learning can be success if the goal in every learning schemes are securely achieved. Once we found that the goal in step one is not achieve, the backup plan should be ready to implement. The readiness of lecturer and student to involve in active learning environment also should be considered, the guideline for facilitator and instructional module for students could be a big help for it.

\subsection{Evaluation}

The data shows that $90 \%$ of students in experiment class are pass the minimum passing grade of the course (minimum grade for Character Building: Pancasila course is B) with average final score is 85 . If we compare the score of experiment class to non-experiment class, we can see that experiment class have a better score than non-experiment class as explain with Figure 1.Graphic in Figure 1. shows that learning result of experiment class, which is implement transformative learning model, is better than learning result of non-experiment class. It indicates that transformative learning model can increase the students' performance. 


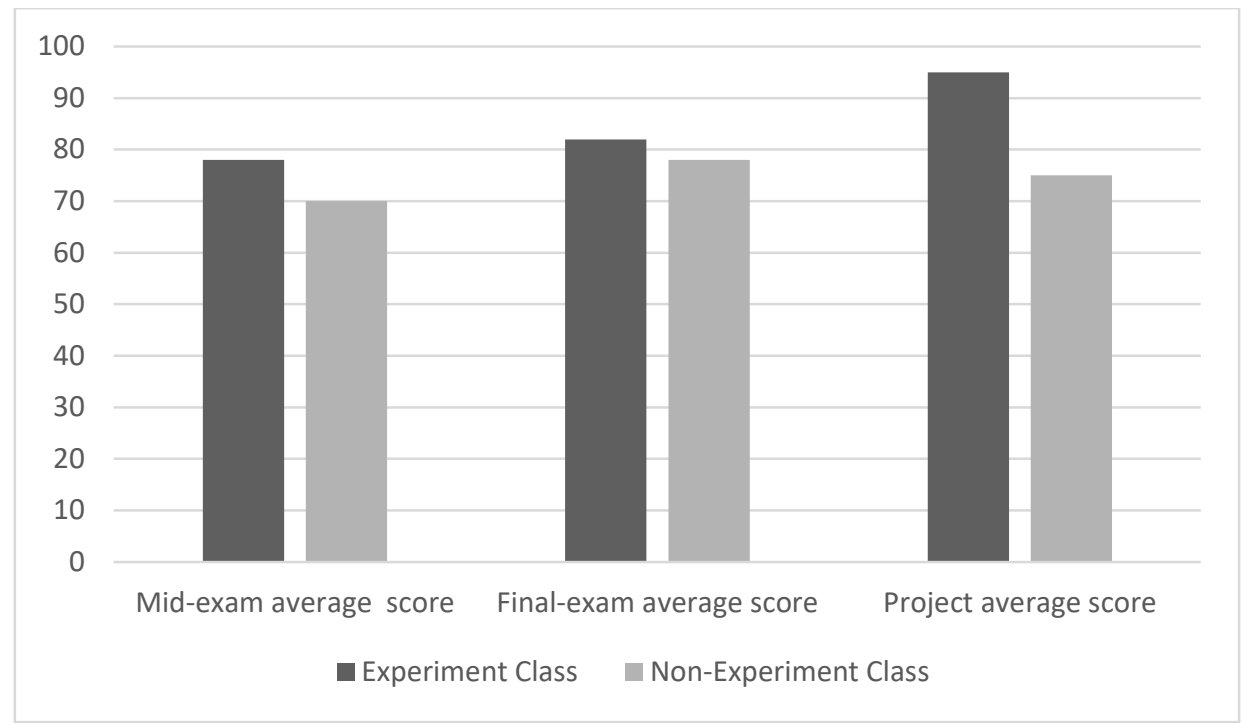

Figure 1.Comparison of Experiment Class and Non-Experiment Class.

Meanwhile, data of assessment result of transformative learning model using ARCS components shows that students give a positive respond on attention, relevance, confidence, and satisfaction criteria. In attention criteria that focus on question whether students are interest in the course or not, $95 \%$ of respondent respond that they interest in the course which is $34 \%$ of it explain that the course is challenging and interactive, so they feel excited to join on the course. While in relevance criteria that focus on question whether students find the relevancy of course with their expectation, $93 \%$ of respondent think that the course have relevancy of course which is $24 \%$ of it think that the course can help them to contribute in the community with a good character as mandated by Pancasila. In confidence criteria, $84 \%$ of respondent respond that they confidence to success on the course which is $30 \%$ of it think that the help of facilitator and support from available resources is the support system to success on the course. And the last, in the satisfaction criteria that focus on question whether the course have transformed their selves into a better person or not, $83 \%$ of respondent respond that they are satisfied with the course which is $59 \%$ of it think that because they do some real project it is transform them to be a better person. The data shows that transformative learning model can solve the previous learning problem in Character Building: Pancasila course.

\section{CONCLUSION}

This research already combines the two most challenging topics in higher education research, "transformative learning" and "character building", both topics are unique and need to be explored. In transformative learning topics, research on developing learning model in higher education become the trend, so that many researches explore this topic. One of the researches is from Richard Kiely that discuss the transformative learning model for service learning. This research use longitudinal research study for explaining how students experience the process of transformational learning in service-learning [13]. The research discuss how transformative learning can be applied in service learning, however the researcher suggests that researchers can explore the discussion on using more precise methods, disciplinary-based 
outcomes, and reflective techniques. To answer the recommendation, our research trying to discuss how to develop transformative learning model based on precise method which is use transformative learning systems model for higher education. Otherwise, our research also discuss how transformative learning can support the achievement of learning outcomes by conducting learning assessment and evaluation.

Meanwhile in character building research topics, we found that research that discuss the new model of learning in character building also become trend amongst researcher in education, however none of the research that apply transformative learning in character building program, especially in Character Building: Pancasila course. However, many researchers that discuss how important character building, especially in Indonesia, on building the future nation. One of the research is research from F Rokhman , A Syaifudin, and Yuliati is discuss on how education has been considered as the centre of excellence in preparing human's excellent characters [11]. One of the researchers' recommendation is to trigger an education system that force students to apply Pancasila in real life. To answer that recommendation, we believe that transformative learning is the best learning model since the objectives of transformative learning is to make a social change.

The implementation of transformative learning in character building course is a new approach in higher education system. Through this research, so the transformative learning model can be alternative of learning model for character building courses to support the nations character building in preparing peace, justice, and strong institution in Indonesia. Researchers believe that in developing affective domain, it needs learning activity that increase the students' skills on finding, constructing, and transforming their own knowledge, therefore transformative learning can be one of the appropriate solutions to answer the learning needs.

Furthermore, researchers see the opportunity to explore the research on developing training model on preparing lecturer to become transformative learning facilitator, considering the challenge that researchers found in this research on preparing lecturer to become facilitator. The research on developing independence learning media or resources can also become a further topic to be explore, considering transformative learning is a student-centered learning model, so it needs high awareness and independency from students to support their success on the learning.

\section{REFERENCES}

[1] J. Mezirow, "Transformative Learning as Discourse," J. Transform. Educ., vol. 1, no. 1, pp. 58-63, Jan. 2003.

[2] A. Kitchenham, "The Evolution of John Mezirow's Transformative Learning Theory," J. Transform. Educ., vol. 6, no. 2, pp. 104-123, 2008.

[3] M. Newman, "Calling Transformative Learning Into Question," Adult Educ. Q., vol. 62, no. 1, pp. 36-55, Feb. 2012.

[4] J. Mezirow, Transformative dimensions of adult learning., vol. 93. 1991.

[5] Y. Miarso, Menyamai Benih Teknologi Pendidikan. Jakarta: Kencana, 2007.

[6] J. M. Dirkx, "Transformative Learning Theory in the Practice of Adult Education: An Overview," PAACE J. Lifelong Learn., vol. 7, pp. 1-14, 1998.

[7] R. J. Fugo and J. A. Fugo, "Building Character," Ann. Ophthalmol., vol. 38, no. 2, pp. 95-96, 2006.

[8] B. Martin and C. Reigeluth, "Afective Education and the Affective Domain: Implications for Instructional-Design Theories and Models," in Instructional-Design 
Theories and Models: Building a Common Knowledge Base Volume II, II., C. Reigeluth, Ed. New York: Routledge, 2009, p. 485.

[9] D. Siswoyo, "Philosophy of Education in Indonesia: Theory and Thoughts of Institutionalized State (PANCASILA)," Asian Soc. Sci., vol. 9, no. 12, Aug. 2013.

[10] S. Nishimura, "The Development of Pancasila Moral Education in Indonesia," Southeast Asian Stud., vol. 33, no. 3, pp. 303-316, 1995.

[11] F. Rokhman, M. Hum, A. Syaifudin, and Yuliati, "Character Education for Golden Generation 2045 (National Character Building for Indonesian Golden Years)," Procedia - Soc. Behav. Sci., vol. 141, pp. 1161-1165, Aug. 2014.

[12] Ubaidah, Transfotmative Learning Model Development in Character Building: Pancasila Course. Jakarta: State University of Jakarta, 2017.

[13] R. Kiely, "A transformative learning model for service-learning: A longitudinal case study," Michigan J. community Serv. Learn., vol. 12, no. 1, pp. 5-22, 2005. 